\section{Evaluation of Methods for Flowering Advancement of Herbaceous Peonies}

\author{
Abraham H. Halevy ${ }^{1}$ \\ The Hebrew University of Jerusalem, Department of Horticulture, P.O. Box \\ 12, Rehovot 76100, Israel
}

Menashe Levi, Menashe Cohen, and Vered Naor
Avnei Eitan Experiment Station, Golan Heights, Israel

Additional index words. dormancy, gibberellin, Paeonia lactiflora

\begin{abstract}
Experiments to advance early production of herbaceous peony (Paeonia lactiflora Pall.) flowers were conducted over 8 years in the higher elevation, cooler regions of Israel. Anatomical studies during the summer revealed that flower bud initiation of apical buds in the crowns began at the end of July and continued also in lateral buds from mid-August until the plants became dormant in mid-November. Container-grown plants of various cultivars were moved to cold rooms maintained for 10 to 13 weeks at $2{ }^{\circ} \mathrm{C}$, from mid-August to mid-October, then drenched with $250 \mathrm{~mL}$ of various concentrations of $\mathrm{GA}_{3}$ and transferred to a greenhouse. The optimal $\mathrm{GA}_{3}$ concentration for flower production was 100 $\mathbf{m g} \cdot \mathbf{L}^{-1}$. Plants treated in this way flowered 2-3 months before the natural flowering period. Field-grown plants in uncovered greenhouse structures were exposed to natural winter cold temperatures $\left(0-10{ }^{\circ} \mathrm{C}\right)$, until they had received various chill units according to a "dynamic model" (for details see Erez et al., 1988). The crowns were then drenched with various amounts and concentrations of $\mathrm{GA}_{3}$, and the greenhouses were covered with plastic sheets. The optimal chill units for most cultivars was 40 and the optimal $\mathrm{GA}_{3}$ drench treatment was $250 \mathrm{~mL}$ of $100 \mathrm{mg} \cdot \mathrm{L}^{-1}$. Covered and $\mathrm{GA}_{3}$-treated field-grown plants flowered $\approx 1$ month earlier than untreated plants grown in the open field. The $\mathbf{G A}_{3}$ treatment also greatly increased the number of produced flowers.
\end{abstract}

Herbaceous peony is primarily derived from Paeonia lactiflora Pall., native to northeast Asia. Some cultivars (cvs.) are hybrids of $P$. lactiflora and $P$. officinalis L. native to southern France (Bailey, 1916; Everett, 1981; Rogers, 1995). Peonies are widely used as garden plants in temperate climate regions, but are less common as cut flowers, in spite of their beauty, because of their short flowering season.

Flower bud initiation commences in mid to late summer, after the old flowers have been cut or senesced. Plants continue to initiate flowers until they become dormant (Byrne and Halevy, 1986). All above-ground parts of herbaceous peonies dry completely in late autumn and the plant enters dormancy. The parts of the plant remaining below ground is a "crown" (tuberous compressed rhizome) with roots and renewal buds, which emerge and begin to grow in the spring, after their dormancy is broken (Wilkins and Halevy, 1985). Peonies are grown mainly in cold climates. They require a certain number of cold tem-

\footnotetext{
Received for publication 20 June 2001. Accepted for publication 20 Mar. 2002. This research was supported by research grants from the Chief Scientist of the Israel Ministry of Agriculture and by Pearlstein Family Fund for research in ornamental horticulture at the Hebrew Univ. We thank the donors for their support. We thank Dr. Hillary Voet, Dept. of Statistics, The Hebrew Univ. of Jerusalem, for her help in statistical data analyses. 'Corresponding author: Fax. +972-8-9468263, E-mail address: ahalevy@agri.huji.ac.il
}

perature hours to break their bud dormancy and enable shoot growth and flower development (Wilkins and Halevy, 1985).

Peonies have been reported to flower successfully in areas with at least 2 to 3 months of freezing temperatures (Post, 1952). However, Byrne and Halevy (1986) found that dormancy of two cut-flower cvs. of containerized herbaceous peony ('Festiva Maxima' and 'Sara Bernhardt') was broken satisfactorily after 8 weeks storage at 1 or $5^{\circ} \mathrm{C}$, and upon transfer to a greenhouse heated to $17^{\circ} \mathrm{C}$, they bloomed in 6 to 10 weeks. $\mathrm{GA}_{3}$ was not applied in this study. Many of the flowering shoots did not reach anthesis and most flower buds aborted. Evans et al. (1990) advanced shoot emergence of noncooled crowns by drenching them with $2000 \mathrm{mg} \cdot \mathrm{L}^{-1} \mathrm{GA}_{3}$, but all flower buds aborted. $\mathrm{GA}_{3}$ is known to partially and sometimes even completely replace the cold requirement for breaking dormancy and for flower initiation (Metzger, 1995).

Cut peony flowers are highly valued in the market, but they are available for only a short period in late spring and early summer. The overall aim of this study, therefore, was to prolong the marketing period by advancing the flowering time. The specific objectives of the present study were to 1) determine more accurately when flower initiation occurs under field conditions in the Golan Heights; 2) determine field cooling requirement for specific cultivars; 3 ) determine whether cooling plus $\mathrm{GA}_{3}$ combination would promote flowering; and 4) determine whether $\mathrm{GA}_{3}$ levels, lower than $2000 \mathrm{mg} \cdot \mathrm{L}^{-1}$, would still enhance shoot emergence without aborting flowers.
Flower initiation and development. Anatomical studies were conducted with belowground buds of two cvs., 'Sara Bernhardt' (SB) and 'Karl Rosenfeld' (KR), during the summers of 1993 and 1994. Crowns were obtained from 3- and 4-year-old plants that were field-grown in the Golan Heights $\left(32^{\circ} 33^{\prime} \mathrm{N}, 35^{\circ} 32^{\prime} \mathrm{E}\right)$. Temperature in the Golan Heights (600 to $800 \mathrm{~m}$ elevation) varied from 2 to $28^{\circ} \mathrm{C}$ in winter and from 18 to $32{ }^{\circ} \mathrm{C}$ in summer. Midday photosynthetic photon flux ranged from 780 to $970 \mu \mathrm{mol} \cdot \mathrm{m}^{-2} \cdot \mathrm{s}^{-1}$ in winter and from 890 to $1300 \mu \mathrm{mol} \cdot \mathrm{m}^{-2} \cdot \mathrm{s}^{-1}$ in summer. Fresh apical and lateral buds were collected every 2 weeks from 1 June to the end of October and dissected for observation under a microscope. Five plants of each cultivar were examined at each sampling date.

All the experiments on flowering control started with artificial or natural cooling and terminated at the end of flowering.

Flowering of container-grown plants. The aim of these experiments was to obtain very early flowering by artificial cooling of potted plants in the cold room and forcing them to bloom in the greenhouse. Containerized plants held in a saran net-house (15\% shade) were used as controls.

Experiment 1. Cooling of cvs. SB and KR began at the end of Aug. 1993, when most central buds had already initiated flower buds as checked by dissection and microscopic observation of three crowns per cultivar. Preliminary trials suggested that beginning cooling of plants before mid-August was not effective to enable flowering (Halevy et al., 1995).

Three-year-old crowns, field-grown in the Golan Heights, were planted one per pot in 15$\mathrm{L}$ containers in a growing medium of equal volumes of volcanic gravel and peat, were cooled at $2{ }^{\circ} \mathrm{C}$ for 10 weeks beginning in 25 Aug. They were then drenched with $250 \mathrm{~mL}$ of 250 or $500 \mathrm{mg} \cdot \mathrm{L}^{-1} \mathrm{GA}_{3}$ (ICI, United Kingdom) and transferred to a greenhouse heated to a minimum of $14^{\circ} \mathrm{C}$.

Experiment 2. In the next year (1994), 4year-old SB containerized plants were cooled at $2{ }^{\circ} \mathrm{C}$ for 13 weeks, drenched with $250 \mathrm{~mL}$ of $100 \mathrm{mg} \cdot \mathrm{L}^{-1} \mathrm{GA}_{3}$ and then moved on 3 Nov. to either a heated (to $14{ }^{\circ} \mathrm{C}$ ) or an unheated greenhouse. Temperatures in the unheated greenhouse varied from 8 to $10^{\circ} \mathrm{C}$ at night and from 16 to $26^{\circ} \mathrm{C}$ during the day in both greenhouses. Average temperature in the heated greenhouse was $20^{\circ} \mathrm{C}$ and $17^{\circ} \mathrm{C}$ in the unheated greenhouse. Ten plants were used in each treatment.

Experiment 3. Forcing field-grown plants The experiments were conducted during 199394 season with field-grown plants raised in a cool region of Israel - the Golan Heights. Fieldgrown plants grew either constantly uncovered, to observe the natural flowering season, or in an unheated greenhouse covered with polyethylene sheets at two dates (14 or 24 Jan. 1994). Plants were divided into four randomized blocks, with each treatment containing five plants and treated with $\mathrm{GA}_{3}$ as detailed 
below. Three cultivars were tested: SB, KR, and 'Duchesse de Nemours' (DN).

a) Open field-grown plants. Temperature conditions in the open field during the winter months ranged from 2 to $8^{\circ} \mathrm{C}$ at night and from 8 to $28^{\circ} \mathrm{C}$ during the day (average temperature $17^{\circ} \mathrm{C}$ ). The following treatments were applied:

1) Untreated control.

2) Drenched with $250 \mathrm{~mL}$ of $100 \mathrm{mg} \cdot \mathrm{L}^{-1}$ $\mathrm{GA}_{3}$ on 3 Mar.

3) Drenched with $250 \mathrm{~mL}$ of $100 \mathrm{mg} \cdot \mathrm{L}^{-1}$ $\mathrm{GA}_{3}$ on 3 and 20 Mar.

4) Drenched as in treatment 3 and sprayed with $100 \mathrm{mg} \cdot \mathrm{L}^{-1} \mathrm{GA}_{3}$ on $4 \mathrm{Apr}$. Crowns were drenched with $\mathrm{GA}_{3}$ prior to natural sprouting and spray was applied $10 \mathrm{~d}$ after sprouting.

b) Covered field-grown plants. Plants of the same cultivars and age as those of open field were grown in uncovered greenhouse structures adjacent to the open-field plants. They were initially exposed to the ambient cold winter weather and then the greenhouse was covered with clear polyethylene sheets either on 14 or 28 Jan. to obtain two durations of chilling before covering. Temperature in the covered greenhouses varied from 6 to $28^{\circ} \mathrm{C}$ (average temperature $19^{\circ} \mathrm{C}$ ). Plants were either not drenched or drenched $2 \mathrm{~d}$ after they were covered with $250 \mathrm{~mL}$ of $100 \mathrm{mg} \cdot \mathrm{L}^{-1} \mathrm{GA}_{3}$.

The following parameters were recorded: number of flowers per plant, flowering period, stem length, and strength (means of all flowering stems per treatment). Stem strength was determined by measuring the angle of stem bending when held horizontally, $\approx 5 \mathrm{~cm}$ from the cut end of the cut flowering shoot.

Experiment 4. Evaluation of optimal $\mathrm{GA}_{3}$ concentration. Four-year-old SB and DN plants were drenched with $250 \mathrm{~mL}$ of $\mathrm{GA}_{3}$ at various concentrations (as detailed in Fig. 1) on $16 \mathrm{Jan}$. 1995 , the day the greenhouse was covered with plastic sheets. Twenty plants were used for each cv. and treatment arranged in randomized blocks of five plants per treatment and cv. The number of shoots per plant and the number of flowers produced per plant were recorded.

Experiment 5 . In the following year (199697), 3-year-old SB, KR, and DN plants were covered on two dates-24 Jan. and 6 Feb. - to check the response of the plants to $\mathrm{GA}_{3}$ drench after they received two durations of chilling. Two $\mathrm{GA}_{3}$ treatments were included in this experiment: 1) $\mathrm{GA}_{3}$ drench at $100 \mathrm{mg} \cdot \mathrm{L}^{-1}$ on the day the greenhouse was covered, and 2) $\mathrm{GA}_{3}$ drench as in treatment 1 and $100 \mathrm{mg} \cdot \mathrm{L}^{-1}$ $\mathrm{GA}_{3}$ sprayed $10 \mathrm{~d}$ later.

Experiment 6. Evaluation of the number of chill units required before covering. The experiment was conducted twice in 1996-97 and 1997-98. Three- and 4-year-old SB and DN plants were grown in greenhouses that were covered with plastic at different dates in the winter, after being exposed to different chill units. They were drenched with $250 \mathrm{~mL}$ of 100 $\mathrm{mg} \cdot \mathrm{L}^{-1} \mathrm{GA}_{3}$ on the day of covering. The number of chill units according to the "dynamic model" of Fishman et al. (1987a, 1987b) and Erez et al. (1988) was recorded daily. The chill units for the various areas of Israel is com-

Table 1. Effect of cooling and $\mathrm{GA}_{3}$ application on flowering of 3 years old container-grown plants of 'Sara Bernhardt' (SB) and 'Karl Rosenfeld' (KR) peonies. Plants were either not cooled (-) or cooled (+) for 10 weeks at $2^{\circ} \mathrm{C}$, and they were either not treated $(-)$ or drenched with $250 \mathrm{~mL}$ of $\mathrm{GA}_{3}(+)$. Plants were grown in a greenhouse heated to $14^{\circ} \mathrm{C}$. Means of 10 replicates \pm SE.

\begin{tabular}{lcccccc}
\hline \hline Cultivar & $\begin{array}{c}\text { Treatment } \\
(+-)\end{array}$ & $\begin{array}{c}\mathrm{GA}_{3} \\
\left(\mathrm{mg} \cdot \mathrm{L}^{-1}\right)\end{array}$ & $\begin{array}{c}\text { Flowering } \\
(\%)\end{array}$ & $\begin{array}{c}\text { No. of } \\
\text { flowers per } \\
\text { plant }\end{array}$ & $\begin{array}{c}\text { Length of } \\
\text { flowering } \\
\text { stem }(\mathrm{cm})^{\mathrm{z}}\end{array}$ & $\begin{array}{c}\text { Flowering } \\
\text { period }^{\mathrm{y}}\end{array}$ \\
\hline SB & - & 0 & 0 & --- & -- & --- \\
& + & 0 & 50 & $1.5 \pm 0.3$ & $55.2 \pm 3.3$ & 16-29 Jan. \\
& + & 250 & 70 & $3.4 \pm 1.1$ & $59.6 \pm 3.8$ & 14-27 Jan. \\
KR & + & 500 & 70 & $3.1 \pm 1.0$ & $59.5 \pm 4.1$ & 12-25 Jan. \\
& - & 0 & 40 & $1.0 \pm 0.2$ & $54.8 \pm 3.2$ & 14-26 Jan. \\
& + & 0 & 60 & $1.8 \pm 0.4$ & $51.2 \pm 2.4$ & 16-29 Jan. \\
& + & 250 & 70 & $3.2 \pm 1.3$ & $54.0 \pm 3.6$ & 12-26 Jan. \\
& + & 500 & 50 & $4.8 \pm 1.6$ & $58.9 \pm 3.9$ & 11-24 Jan.
\end{tabular}

${ }^{2}$ Data of nonflowering plants were not included in the analysis.

'From the first to the last harvested flower.

Table 2. Effect of cooling container-grown 4-year-old 'Sara Bernhardt' peony plants for 13 weeks at $2{ }^{\circ} \mathrm{C}$, drenched with $250 \mathrm{~mL}$ of $100 \mathrm{mg} \cdot \mathrm{L}^{-1} \mathrm{GA}_{3}(+)$ and grown in a heated (to $\left.14{ }^{\circ} \mathrm{C}\right)(+)$ or unheated $(-)$ greenhouse, on flowering parameters. Means of 10 replicates \pm SE.

\begin{tabular}{|c|c|c|c|c|c|c|}
\hline $\begin{array}{l}\mathrm{GA}_{3} \\
(+-)\end{array}$ & $\begin{array}{c}\text { Greenhouse } \\
\text { heating } \\
(+-)\end{array}$ & $\begin{array}{c}\text { Flowering } \\
\text { period }\end{array}$ & $\begin{array}{c}\text { Days to } \\
\text { beginning of } \\
\text { flowering }\end{array}$ & $\begin{array}{c}\text { Flowering } \\
(\%)\end{array}$ & $\begin{array}{l}\text { No. of } \\
\text { flowers per } \\
\text { plant }\end{array}$ & $\begin{array}{l}\text { Length of } \\
\text { flowering } \\
\text { stem }(\mathrm{cm})\end{array}$ \\
\hline+ & + & 31 Dec.-12 Jan. & $90 \pm 1.1$ & 70 & $4.6 \pm 0.9$ & $72.3 \pm 3.1$ \\
\hline - & + & 6-12 Jan. & $96 \pm 2.6$ & 50 & $1.0 \pm 0.2$ & $70.6 \pm 3.0$ \\
\hline+ & - & 8-16 Jan. & $98 \pm 2.7$ & 90 & $4.6 \pm 0.8$ & $66.8 \pm 2.6$ \\
\hline- & - & 31 Dec.-19 Jan. & $90 \pm 1.9$ & 50 & $2.0 \pm 0.3$ & $68.5 \pm 2.8$ \\
\hline \multicolumn{7}{|c|}{ Significance of } \\
\hline GA & & & NS & & $<0.0001$ & NS \\
\hline $\mathrm{Hea}$ & & & NS & & NS & NS \\
\hline
\end{tabular}

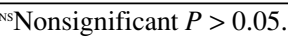

puted and reported by the Meteorological Service of Israel. The computerized model accounts for the hourly temperatures in relation to the temperatures before and after each recorded temperature. A chill unit corresponds to exposure for $24 \mathrm{~h}$ to $6^{\circ} \mathrm{C}$. The number of flowers produced per plant were recorded.

Statistical analysis. Comparison of treatments was performed by two-way analysis of variance $\left(\mathrm{GA}_{3} \times\right.$ heating or $\mathrm{GA}_{3} \times$ cultivar $)$, using cover date as a blocking factor, where relevant. The effect of number of chill units or of $\mathrm{GA}_{3}$ concentration was analyzed by parabolic regression. An arcsin transformation was used on percentage data prior to analysis.

\section{Results}

Flower initiation and development. Until mid-July, all buds were vegetative. The first flower initials were observed in apical (central) buds at the end of July in SB and 2 weeks later in KR. Lateral buds remained vegetative until mid-August. During August, $\approx 85 \%$ of the central buds initiated flowers, first in the buds having large apical meristems and later also in the smaller central buds, and they continued to develop during the summer. Starting from late August, flower initiation began also in large lateral buds, and it continued until the plants became dormant in November. About $35 \%$ of these lateral buds did not complete their differentiation before dormancy.

Flowering of container-grown plants. Experiment 1 . Early flowering was achieved in containerized plants by combined treatments of cooling and $\mathrm{GA}_{3}$ (Table 1). Drenching with
$500 \mathrm{mg} \cdot \mathrm{L}^{-1} \mathrm{GA}_{3}$ was excessive, since it caused flower malformation and weak stems (data not shown). Most plants that were recorded as not flowering did form flower buds that aborted later. We suspected that growing in a closed heated greenhouse promoted flower abortion, as shown in an earlier study in California (Byrne and Halevy, 1986).

Experiment 2. In the next year, 4-year-old $\mathrm{SB}$ containerized plants were grown after cooling in either heated or unheated greenhouses. The data of Table 2 shows that it was possible to obtain very early flowering of marketable quality SB flowers in January by combined treatments of cooling and $\mathrm{GA}_{3}$. Growing in unheated greenhouses was preferable, because flowering percentage was higher and stems were stronger (data not shown).

This method of cultivation was evaluated in the four succeeding years with several cvs. The optimal cooling period varied from 10 to 13 weeks, the optimal time for the beginning of cooling varied between cvs. from midAugust to mid-October (data not shown). The optimal $\mathrm{GA}_{3}$ treatment was a soil drench with $250 \mathrm{~mL}$ of $100 \mathrm{mg} \cdot \mathrm{L}^{-1}$ (data not shown) as was found also for plants grown in ground beds (Fig. 1).

Experiment 3. Forcing field-grown plants. Beginning of the natural flowering of open field-grown plants of the three cvs. (SB, KR, DN) was at the end of April. Plants continued blooming for 2-3 weeks (Table 3 ). $\mathrm{GA}_{3}$ treatments advanced flowering of SB and KR by only 1 week. However, $\mathrm{GA}_{3}$ more than doubled flower production in two cvs. (KR and DN). One $\mathrm{GA}_{3}$ drench was sufficient for $\mathrm{SB}$ and $\mathrm{KR}$. 

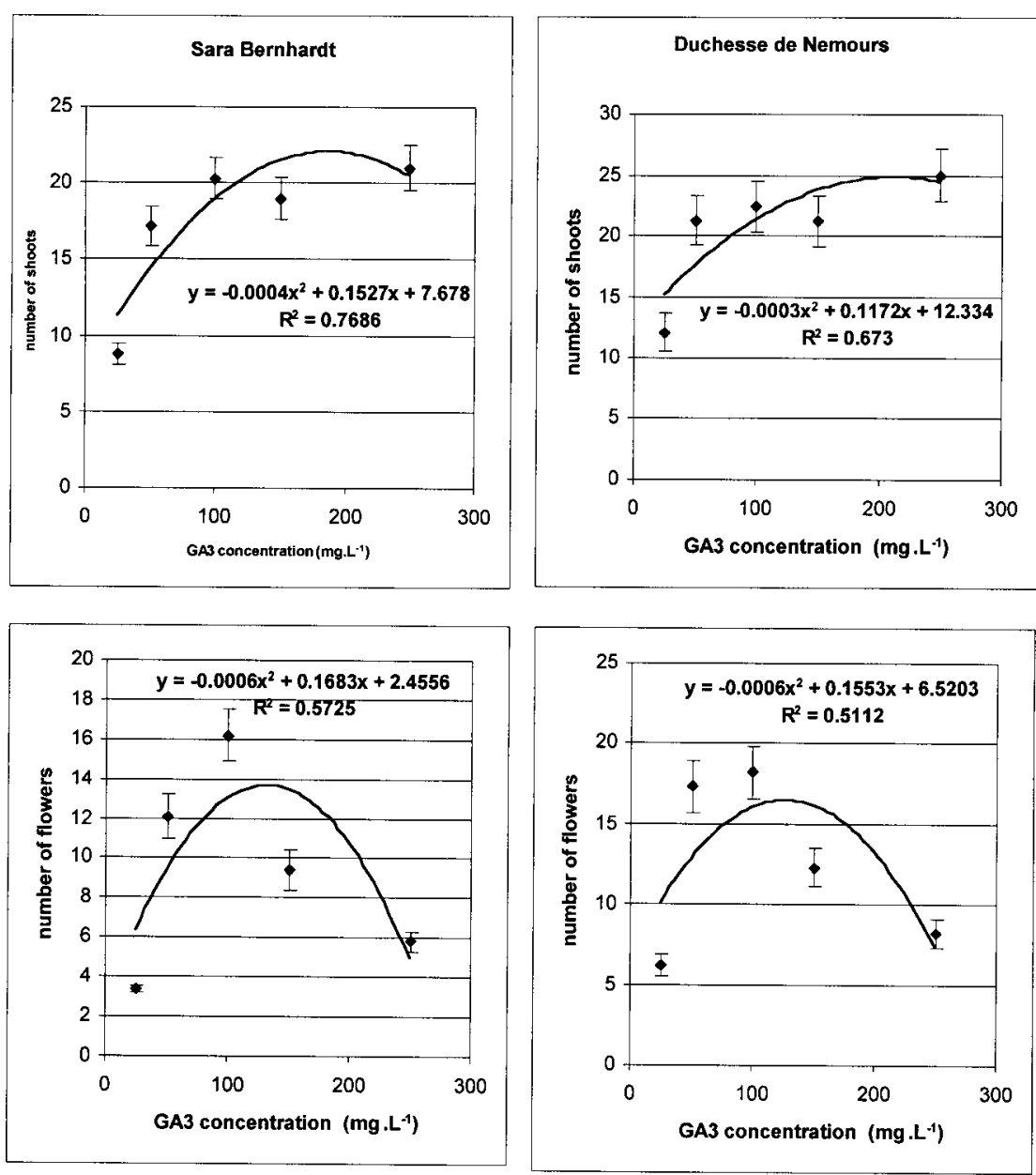

Fig. 1. Effect of drenching 4-year-old 'Sara Bernhardt' and 'Duchesse de Nemours' peonies with various concentrations of $\mathrm{GA}_{3}$ on total number of shoots and number of flowering shoots per plant. Drench $(250$ $\mathrm{mL}$ ) was applied on the day the greenhouses were covered with plastic (16 Jan.).

Repeated $\mathrm{GA}_{3}$ applications (drench or spray) reduced flower production of SB by promoting flower abortion. Stem strength was generally reduced by repeated $\mathrm{GA}_{3}$ applications (data not shown).

Covering field plants in unheated plastic structures (Table 4 ) advanced flowering by $\approx 1$ month as compared to open field-grown plants adjacent to the covered plants (compare data in Table 3 with Table 4). Flower yield was somewhat lower than in the open field, but the stems were longer. $\mathrm{GA}_{3}$ treatment advanced flowering by $\approx 1$ week and greatly increased flower yield.

In all cases, one $\mathrm{GA}_{3}$ drench greatly increased flower production. However, excessive $\mathrm{GA}_{3}$ was detrimental for SB (Table 3). The next test was therefore performed to evalu- ate the optimal $\mathrm{GA}_{3}$ drench concentration required for flower production.

Evaluation of optimal $\mathrm{GA}_{3}$ concentration. Experiment 4. The test was conducted with 4year-old SB and DN plants. They were drenched and the greenhouse was covered on 16 Jan. Results in Fig. 1 show that a drench with $100 \mathrm{mg} \cdot \mathrm{L}^{-1} \mathrm{GA}_{3}$ was optimal. This concentration was, therefore, used in all the following trials and is recommended for commercial applications.

Experiment 5. Since $\mathrm{GA}_{3}$ treatment hastened flowering and increased flower production, untreated plants were not included in the tests conducted in the following years. In the following year the winter climate was warmer than in the previous years and, therefore, covering the plants was delayed to let them obtain more days of cool weather (Table 5).

Two $\mathrm{GA}_{3}$ treatments were included in this year: 1) $\mathrm{GA}_{3}$ drench at $100 \mathrm{mg} \cdot \mathrm{L}^{-1}$ on the day the greenhouse was covered, and 2) $\mathrm{GA}_{3}$ drench as in (1) and $100 \mathrm{mg} \cdot \mathrm{L}^{-1} \mathrm{GA}_{3}$ spray $10 \mathrm{~d}$ later. The results (Table 5) show that double $\mathrm{GA}_{3}$ treatment of drench and spray was in most cases not better than drench alone, and in some cases reduced flowering percentage by promoting flower abortion.

Experiment 6. Evaluation of the number of chill units required before covering. Results of Table 5 indicate a possible difference in chilling requirement of the various cvs. The lower chilling requirement was in DN and the higher in KR, which did not bloom at the early covering date without a $\mathrm{GA}_{3}$ drench (Table 5). These results also indicate that the date is not a reliable criterion for the appropriate time to cover the plants after receiving sufficient chilling. We, therefore, decided to examine the use of the chill units according to the "dynamic model" (Erez et al., 1988) as a more objective criterion for covering the greenhouses.

Results in Fig. 2 show that chilling saturation was reached at 42 chill units for cv. SB and at 36 chill units for cv. DN. These criteria are used commercially now to determine the appropriate time to cover the greenhouses with plastic in the winter to obtain early flowering.

\section{Discussion}

The developmental behavior of herbaceous peonies is similar in some ways to that of deciduous fruit trees. They bloom in the spring, initiate their flowers during the summer, and shed their leaves and enter dormancy in late autumn. However, unlike deciduous trees, foliage senescence and dormancy are not induced by short days in peonies and flower formation and development are also unaffected by photoperiod (Byrne and Halevy, 1986; Wilkins and Halevy, 1985).

The factors inducing flower formation, leaf abscission, and bud dormancy of peonies are unknown. Breaking of bud dormancy requires exposure to a certain chilling period, as known for most deciduous trees (Erez et al., 1998). In peonies, this requirement can be achieved not only by freezing temperatures, as assumed previously (Post, 1952), but also by low temperatures a little above freezing (Byrne and Halevy, 1986; Tables 1 and 2). Application of $\mathrm{GA}_{3}$ directly to the dormant buds on the crown can complement the cold requirement for breaking dormancy and promote bud sprouting and shoot growth. In herbaceous peonies, as in roses, all growing shoots will initiate

Table 3. Effect of $100 \mathrm{mg} \cdot \mathrm{L}^{-1} \mathrm{GA}_{3}$ treatments, applied as one (3 Mar.) or two ( 3 and 20 Mar.) soil drenches of $250 \mathrm{~mL}$ per plant or as two drenches and spray (4 Apr.), on flowering of 3-year-old, open field-grown plants. Means of 20 replicates \pm SE.

\begin{tabular}{|c|c|c|c|c|c|c|c|c|c|}
\hline \multirow[b]{3}{*}{ Treatment } & \multicolumn{9}{|c|}{ Cultivars } \\
\hline & \multicolumn{3}{|c|}{ Sara Bernhardt } & \multicolumn{3}{|c|}{ Karl Rosenfeld } & \multicolumn{3}{|c|}{ D. de Nemours } \\
\hline & $\begin{array}{l}\text { Flowers } \\
\text { per plant }\end{array}$ & $\begin{array}{c}\text { Flowering } \\
\text { period }\end{array}$ & $\begin{array}{l}\text { Stem length } \\
(\mathrm{cm})\end{array}$ & $\begin{array}{l}\text { Flowers } \\
\text { per plant }\end{array}$ & $\begin{array}{c}\text { Flowering } \\
\text { period }\end{array}$ & $\begin{array}{l}\text { Stem length } \\
(\mathrm{cm})\end{array}$ & $\begin{array}{l}\text { Flowers } \\
\text { per plant }\end{array}$ & $\begin{array}{c}\text { Flowering } \\
\text { period }\end{array}$ & $\begin{array}{c}\text { Stem length } \\
(\mathrm{cm})\end{array}$ \\
\hline Control & $6.0 \pm 0.6$ & 29 Apr.-12 May & $48.6 \pm 3.4$ & $5.7 \pm 0.1$ & 27 Apr.-14 May & $40.0 \pm 2.3$ & $5.7 \pm 0.4$ & 26 Apr.-14 May & $47.8 \pm 3.4$ \\
\hline One $\mathrm{GA}_{3}$ drench & $9.8 \pm 1.1$ & 20 Apr.-6 May & $54.4 \pm 3.6$ & $11.8 \pm 2.2$ & 20 Apr.-6 May & $37.3 \pm 2.1$ & $13.0 \pm 2.1$ & 24 Apr.-10 May & $32.6 \pm 2.8$ \\
\hline Two $\mathrm{GA}_{3}$ drenches & $5.3 \pm 0.9$ & 22 Apr.-10 May & $44.7 \pm 2.9$ & $19.8 \pm 3.6$ & 21 Apr.-8 May & $37.6 \pm 1.9$ & $12.3 \pm 1.9$ & 23 Apr.-7 May & $42.5 \pm 3.1$ \\
\hline Two $\mathrm{GA}_{3}$ drenches + spray & $3.5 \pm 0.5$ & 22 Apr.-11 May & $41.6 \pm 2.6$ & $20.2 \pm 3.8$ & 20 Apr.-5 May & $37.2 \pm 2.6$ & $13.7 \pm 2.2$ & 23 Apr.-8 May & $41.3 \pm 3.2$ \\
\hline
\end{tabular}


Table 4. Effect of $250 \mathrm{~mL}$ of $100 \mathrm{mg} \cdot \mathrm{L}^{-1} \mathrm{GA}_{3}$ drench to 3-year-old, field-grown peony cvs.- 'Sara Bernhardt' (SB), 'Karl Rosenfeld' (KR), and 'Duchesse de Nemours' (DN)—grown in an unheated greenhouse, covered on two dates, 14 and 28 Jan. Means of 20 replicates \pm SE.

\begin{tabular}{|c|c|c|c|c|c|}
\hline \multicolumn{3}{|c|}{ Treatment } & \multirow[b]{2}{*}{$\begin{array}{l}\text { Flowering } \\
\text { period }\end{array}$} & \multirow[b]{2}{*}{$\begin{array}{l}\text { No. of flowers } \\
\text { per plant }\end{array}$} & \multirow{2}{*}{$\begin{array}{c}\text { Length of } \\
\text { flowering stem } \\
(\mathrm{cm})\end{array}$} \\
\hline Cover date & Cultivar & $\begin{array}{l}\mathrm{GA}_{3} \\
(+-)\end{array}$ & & & \\
\hline \multirow[t]{6}{*}{ 14 Jan. } & SB & + & 25 Mar.-10 Apr. & $3.4 \pm 0.4$ & $56.6 \pm 3.3$ \\
\hline & SB & - & 30 Mar.-18 Apr. & $0.9 \pm 0.2$ & $64.3 \pm 3.6$ \\
\hline & $\mathrm{KR}$ & + & 19 Mar.-6 Apr. & $2.5 \pm 0.3$ & $43.4 \pm 2.8$ \\
\hline & $\mathrm{KR}$ & - & 0 & 0 & 0 \\
\hline & DN & + & 23 Mar.-8 Apr. & $10.4 \pm 1.1$ & $55.0 \pm 3.1$ \\
\hline & DN & - & 29 Mar.-16 Apr. & $2.0 \pm 0.2$ & $59.6 \pm 3.4$ \\
\hline \multirow[t]{6}{*}{28 Jan. } & SB & + & 31 Mar.-16 Apr. & $5.9 \pm 0.6$ & $63.3 \pm 3.6$ \\
\hline & SB & - & 4-24 Apr. & $1.3 \pm 0.2$ & $67.4 \pm 3.6$ \\
\hline & $\mathrm{KR}$ & + & 28 Mar.-15 Apr. & $2.5 \pm 0.3$ & $54.4 \pm 2.9$ \\
\hline & $\mathrm{KR}$ & - & 4-24 Apr. & $0.6 \pm 0.1$ & $60.6 \pm 3.4$ \\
\hline & $\mathrm{DN}$ & + & 29 Mar.-13 Apr. & $7.2 \pm 0.9$ & $57.7 \pm 3.1$ \\
\hline & $\mathrm{DN}$ & - & 4-24 Apr. & $1.1 \pm 0.2$ & $57.5 \pm 3.0$ \\
\hline \multicolumn{6}{|c|}{ Significance of } \\
\hline \multirow{2}{*}{\multicolumn{2}{|c|}{$\begin{array}{l}\text { Cultivar } \times \mathrm{GA}_{3} \\
\text { Cultivar }\end{array}$}} & & & $<0.0001$ & $<0.0001$ \\
\hline & & & & $<0.0001$ & $<0.0538$ \\
\hline \multicolumn{2}{|c|}{$\mathrm{GA}_{3}$} & & & $<0.0001$ & $<0.0001$ \\
\hline \multicolumn{2}{|c|}{ Cover date } & & & NS & $<0.0001$ \\
\hline
\end{tabular}

${ }^{\text {ss Nonsignificant. }}$

Table 5. Effect of $100 \mathrm{mg} \cdot \mathrm{L}^{-1} \mathrm{GA}_{3}$ treatment to 4-year-old, field-grown peony cvs.—'Sara Bernhardt' (SB), 'Karl Rosenfeld' (KR), and 'Duchesse de Nemours' (DN), grown in greenhouses covered on two dates, $24 \mathrm{Jan}$. and $6 \mathrm{Feb}$. Two $\mathrm{GA}_{3}$ treatments at $100 \mathrm{mg} \cdot \mathrm{L}^{-1}$ were included - drench (D) of $250 \mathrm{~mL}$ and drench and spray $(\mathrm{D}+\mathrm{S})$. Means of 20 replicates $\pm \mathrm{SE}$.

\begin{tabular}{|c|c|c|c|c|c|c|}
\hline \multicolumn{3}{|c|}{ Treatment } & \multirow[b]{2}{*}{$\begin{array}{l}\text { Flowering } \\
\text { period }\end{array}$} & \multirow[b]{2}{*}{$\begin{array}{c}\text { Flowering } \\
(\%)\end{array}$} & \multirow[b]{2}{*}{$\begin{array}{l}\text { No. of flowers } \\
\text { per plant }\end{array}$} & \multirow{2}{*}{$\begin{array}{c}\text { Length of } \\
\text { flowering stem } \\
(\mathrm{cm})\end{array}$} \\
\hline Cover date & Cultivar & $\begin{array}{l}\mathrm{GA}_{3} \\
(+-)\end{array}$ & & & & \\
\hline \multirow[t]{6}{*}{24 Jan. } & SB & $\mathrm{D}$ & 30 Mar.-14 Apr. & 80 & $2.8 \pm 0.4$ & $66.4 \pm 3.6$ \\
\hline & SB & $D+S$ & 1-13 Apr. & 90 & $5.2 \pm 0.7$ & $63.3 \pm 3.2$ \\
\hline & $\mathrm{KR}$ & $\mathrm{D}$ & 5-16 Apr. & 65 & $1.2 \pm 0.2$ & $53.0 \pm 2.8$ \\
\hline & $\mathrm{KR}$ & $D+S$ & 30 Mar.-15 Apr. & 20 & $0.5 \pm 0.1$ & $52.8 \pm 2.7$ \\
\hline & DN & D & 28 Mar.-14 Apr. & 100 & $14.5 \pm 1.3$ & $62.4 \pm 3.1$ \\
\hline & DN & $\mathrm{D}+\mathrm{S}$ & 29 Mar.-15 Apr. & 100 & $16.8 \pm 1.4$ & $59.0 \pm 3.0$ \\
\hline \multirow[t]{6}{*}{6 Feb. } & SB & $\mathrm{D}$ & 5-24 Apr. & 100 & $8.2 \pm 0.9$ & $60.3 \pm 3.0$ \\
\hline & SB & $D+S$ & 3-22 Apr. & 85 & $4.9 \pm 0.6$ & $61.4 \pm 3.1$ \\
\hline & KR & $\mathrm{D}$ & 2-22 Apr. & 80 & $4.3 \pm 0.6$ & $47.3 \pm 2.6$ \\
\hline & KR & $D+S$ & 1-21 Apr. & 90 & $7.6 \pm 0.9$ & $53.6 \pm 2.8$ \\
\hline & DN & D & 3-22 Apr. & 100 & $14.7 \pm 1.4$ & $62.7 \pm 3.2$ \\
\hline & DN & $\mathrm{D}+\mathrm{S}$ & 4-22 Apr. & 100 & $14.6 \pm 1.4$ & $58.4 \pm 3.0$ \\
\hline \multicolumn{7}{|c|}{ Significance of } \\
\hline \multirow{2}{*}{\multicolumn{3}{|c|}{$\begin{array}{l}\text { Cultivar } \times \mathrm{GA}_{3} \\
\text { Cultivar }\end{array}$}} & & & NS & NS \\
\hline & & & & & $<0.0001$ & $<0.0001$ \\
\hline \multicolumn{3}{|c|}{$\mathrm{GA}_{3}$} & & & NS & NS \\
\hline \multicolumn{3}{|l|}{ Cover date } & & & $<0.0001$ & NS \\
\hline
\end{tabular}

${ }^{\text {Ns Nonsignificant. }}$

flowers after forming a certain number of leaves depending on the cv. (Halevy, 1984). "Blind shoots" that have reached a certain length are, therefore, not vegetative but shoots that aborted their flower initials. Therefore, the chilling requirement is required to release buds from dormancy, and does not have a specific effect on flower initiation (vernalization). $\mathrm{GA}_{3}$ treatment does not promote flower initiation and differentiation in peonies per se. It is applied to reproductive dormant buds, and is not effective if applied before flower formation (Halevy et al., 1995). Crown drench with $250 \mathrm{~mL}$ of $100 \mathrm{mg} \cdot \mathrm{L}^{-1} \mathrm{GA}_{3}$ was found to be optimal. Too low concentrations caused a low number of shoots to sprout and too high concentrations, or excessive applications, induced sprouting of many shoots but many of them aborted and did not produce flowers (Table 5, Fig. 1). We have also tried application of cytokinins at various concentrations, alone and with $\mathrm{GA}_{3}$, but it also caused multiple sprouting of shoots with aborted flower buds (Halevy et al., 1995).

The method developed in the present study for advancing flowering of field-grown peonies is based on exposure of the plants to ambient cold winter weather until they obtain a sufficient duration of cold temperature. This exposure is supplemented by drenching with $\mathrm{GA}_{3}$ to hasten growth and flowering is promoted by covering the greenhouse and raising the growing temperatures.

Another method for obtaining very early flowering (during January-February) is with container-grown plants. They are artificially cooled at $0-2{ }^{\circ} \mathrm{C}$ for $10-13$ weeks, drenched with $\mathrm{GA}_{3}$, and transferred to the greenhouse. No light is given during cooling, since only crowns without above-ground parts are present during cooling.

The chilling requirement for breaking bud dormancy was found to vary in the various cvs. (Fig. 2). Weather conditions vary at various seasons and locations. Therefore, the time of closing the greenhouses could not be determined by a fixed date. Requirement of cold period was estimated by using chill units, according to the "dynamic model" developed by Fishman et al. (1987a, 1987b) and Erez et al. (1988) for deciduous fruit trees. Attainment of $\approx 40$ chill units is now used by growers to determine the time for closing the greenhouses for most cvs. (Fig. 2). In conclusion, this study formed the basis for developing practical methods for the advancement of flowering in herbaceous peonies, which are used to greatly extend the flowering period.

\section{Literature Cited}

Bailey, L.H. 1916. Paeonia, p. 2432-2433. In: The standard cyclopedia of horticulture. Macmillan, New York.

Byrne, T.G. and A.H. Halevy. 1986. Forcing herbaceous peonies. J. Amer. Soc. Hort. Sci. 111:379383.

HortScience, Vol. 37(6), October 2002 

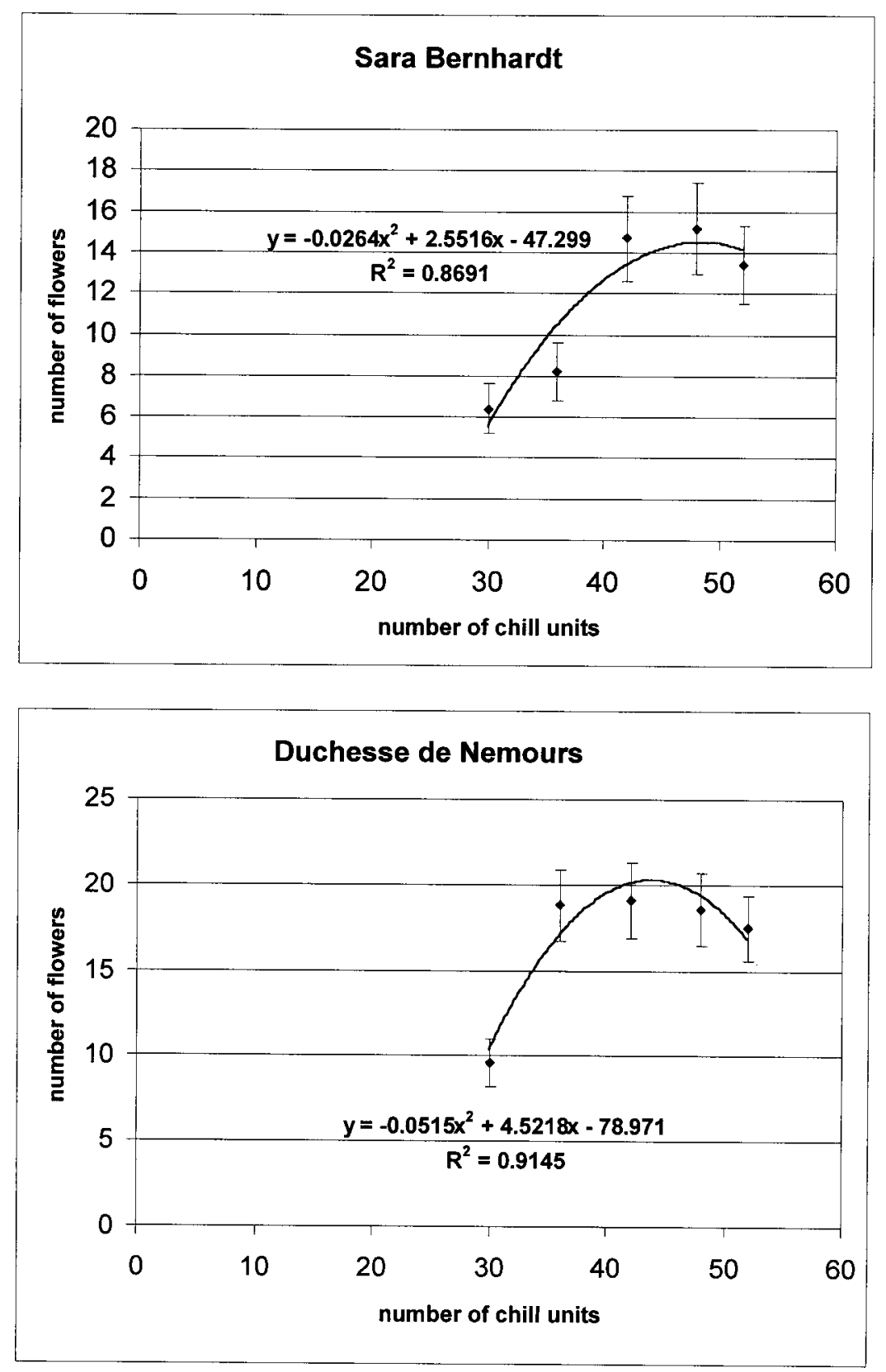

Fig. 2. Effect of covering greenhouses with polyethylene sheets after obtaining various numbers of chill units (see Materials and Methods) on number of flowering shoots per plant of 'Sara Bernhardt' and 'Duchesse de Nemours' peonies.
Erez, A., S. Fishman, Z. Gat, and G.A. Couvillon. 1988. Evaluation of winter climate for breaking bud rest using the dynamic model. Acta Hort. 232:76-89.

Evans, M.R., N.O. Anderson, and H.F. Wilkins. 1990. Temperature and $\mathrm{GA}_{3}$ effects on emergence and flowering of potted Paeonia lactiflora. HortScience 25:923-924.

Everett, T.H. 1981. Peony, p. 2550-2553. In: The New York botanical garden encyclopedia of horticulture. vol. 8.

Fishman, S., A. Erez, and G.A. Couvillon. 1987a. The temperature dependence of dormancy breaking in plants: Computer simulation of processes studies under controlled temperatures. J. Theor. Biol. 126:309-321.

Fishman, S., A. Erez, and G.A. Couvillon. 1987b. The temperature dependence of dormancy breaking in plants: mathematical analysis of a twostep model involving a cooperative transition. J. Theor. Biol. 126:473-483.

Halevy, A.H. 1984. Light and autonomous induction, p. 65-73. In: D. Vince-Prue, B. Thomas, and K.E. Cockshull (eds.). Light and the flowering process. Academic, London.

Halevy, A.H., D. Weiss, V. Naor, M. Cohen, M. Levi, and D. Skuier. 1995. Introduction of herbaceous peony as commercial cut flower in Israel (in Hebrew). Dapi Meida 5:58-62.

Metzger, J.D. 1995. Hormones and reproductive development, p. 619-648. In: P.G. Davis (ed.). Plant hormones, physiology, biochemistry and molecular biology. Kluwer Academic, Dordrecht.

Post, K. 1952. Paeonia, p. 720-727. In: Florist crop production and marketing. Orange Judd, New York.

Rogers, A. 1995. Peonies. Timber Press, Portland, Ore.

Wilkins, H.F. and A.H. Halevy. 1985. Paeonia, p. 2-4. In: A.H. Halevy (ed.). CRC handbook of flowering. vol. IV. CRC Press, Boca Raton, Fla. 